\title{
Number of stems and row spacing on growth and yield of cape gooseberry
}

\author{
Anderson Weber ${ }^{1} \oplus$, Francis Júnior Soldateli2*${ }^{\circledR}$, Alex Oliveira Bitencourt ${ }^{1} \oplus$,

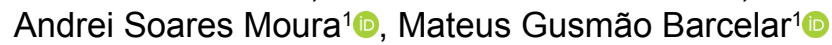 \\ 1 Universidade Federal do Pampa, Itaqui, RS, Brazil. E-mail: andersonweber@unipampa.edu.br; alex.a0460@gmail.com; mouraa541@gmail.com; mateusgusmaobarcelar@gmail.com \\ 2 Universidade Federal de Santa Maria, Santa Maria, RS, Brazil. E-mail: francisjrsoldateli@gmail.com
}

ABSTRACT: This study aimed to evaluate the influence of the number of stems and row spacing on cape gooseberry growth and yield in the open field. A completely randomized block design was adopted in a three-factor arrangement (number of stems $x$ spacings $\times$ evaluations). The spatial arrangements used were the spacing between rows of 3.0 and $1.5 \mathrm{~m}$, keeping $0.5 \mathrm{~m}$ between plants. The formation pruning consisted of maintaining 4,6 and 8 stems per plant. The evaluations were carried out weekly from the pruning until the plant senescence. The height and diameter of the stem showed gradual growth and the number of leaves decreased with the beginning of production during the plant cycle. Plants conducted with four stems showed a larger stem diameter and a greater height in the $1.5 \mathrm{~m}$ spacing between rows, while the number of leaves, fruits and yield increased as the number of stems increased. The largest number of fruits and the highest estimated yields were found in the $1.5 \mathrm{~m}$ spacing between rows, regardless of the number of stems, with an average value of 621 thousand fruits ha-1 and yields of $2.15 \mathrm{t} \mathrm{ha}^{-1}$ for fruits with calyx and $1.70 \mathrm{t} \mathrm{ha}^{-1}$ for fruits without calyx.

Key words: Physalis peruviana L.; pruning; small fruits

\section{Número de hastes e espaçamentos entre fileiras no crescimento e produção de fisális}

RESUMO: O objetivo do trabalho foi avaliar a influência do número de hastes e do espaçamento entre fileiras no crescimento e produção da fisális cultivada em campo aberto. $O$ delineamento experimental utilizado foi de blocos ao acaso em um arranjo trifatorial (número de hastes $\times$ espaçamentos $\times$ avaliações). Os arranjos espaciais utilizados foram os espaçamentos entre fileiras de 3,0 e 1,5 m, mantendo-se 0,5 m entre plantas. A poda de formação consistiu em manter 4, 6 e 8 hastes por planta. As avaliações foram realizadas semanalmente a partir da poda até a senescência da planta. A altura e 0 diâmetro do caule apresentaram crescimento gradual, sendo que o número de folhas decresceu com o início da produção durante 0 ciclo da planta. As plantas conduzidas com 4 hastes apresentaram maior diâmetro da haste e maior altura no espaçamento $1,5 \mathrm{~m}$ entre fileiras, enquanto o número de folhas, frutos e as produtividades aumentaram conforme 0 acréscimo do número de hastes. 0 maior número de frutos e as maiores produtividades estimadas foram constatadas no espaçamento de $1,5 \mathrm{~m}$ entre fileiras, independentemente do número de hastes conduzidas, com valores médios de 621 mil frutos ha-1 $^{-1}$ produtividades de $2,15 \mathrm{t} \mathrm{ha}^{-1}$ para frutos com cálice e de $1,70 \mathrm{tha}^{-1}$ para frutos sem cálice.

Palavras-chave: Physalis peruviana L.; poda; pequenos frutos

\footnotetext{
* Francis Júnior Soldateli - E-mail: francisjrsoldateli@gmail.com (Corresponding author)

Associate Editor: Sérgio Ruffo Roberto
} 


\section{Introduction}

The small fruit sector has instigated producers, traders, and consumers due to the low cost of implantation and production and a high added value (Bendlin et al., 2016), in addition to the demand of the current market for healthier and more attractive products (Olivares-Tenorio et al., 2017). Among the various fruits that make up this group, cape gooseberry (Physalis peruviana L.) is relevant in the human diet with exotic organoleptic properties and expressive content of nutraceutical compounds such as vitamins $A, B$, and $C$, flavonoids, carotenoids, and antioxidants (Pereda et al., 2019).

However, several factors related to the management systems such as plant spacing, and number of stems can limit the expansion of the production of this fruit (Criollo et al., 2014; Muniz et al., 2015; D’Angelo et al., 2017). Furthermore, the cultivation of cape gooseberry depends on the yield, quality, and market potential (Muniz et al., 2014). Thus, the lack of knowledge about cultivation techniques is the main limitation on the production of cape gooseberry, and because of the lack of technical information, most cultural treatments are based on other solanaceous species (Silva et al., 2013; Rodrigues et al., 2018). As a result, there are gaps in the sector that limit production in which the knowledge of crop management is relevant in order to optimize practices and expand the cultivation of the fruit.

Cape gooseberry is an herbaceous plant and has a large branch. These characteristics, combined with the soft-wooded stem, imply in a decumbent growth habit, making pruning and plant tutoring necessary (Muniz et al., 2014). However, the number of stems conducted in cape gooseberry varies widely according to the growing conditions, commonly between one and eight stems per plant (Rodrigues et al., 2013; D’Angelo et al., 2017; Rodrigues et al., 2018). The maintenance of the number of stems alters the flow of water and photosynthates available for the growth and development of the plant, and for the formation of the fruit, being able to promote the reduction of the dimensions and to increase the occurrence of physiological disturbances in the fruits, besides altering the yield (Criollo et al., 2014).

Similar to pruning, the spacing between plants alters growth and yield by interfering in the capture of solar radiation, architecture, aeration of plants, and cultural treatments (Bendlin et al., 2016). In general, the recommended distance for planting is $3.0 \times 1.0$ or $3.0 \times 0.5 \mathrm{~m}$ between rows and plants, respectively (Muniz et al., 2014; Moura et al., 2016). However, vital aspects to the development of the plant are altered according to the cultivation conditions, and its results cannot always be extrapolated from one region to another or from one cultivation system to another (Candian et al., 2017; Mourão et al., 2017). As a result, the study of the cultural treatments of cape gooseberry appears as a primordial aspect in the management of the culture.

Thus, the aim of this work was to evaluate the influence of the number of stems and the spacing between rows on the growth and yield of cape gooseberry cultivated in the open field.

\section{Materials and Methods}

The experiment was carried out in the experimental area of the Federal University of Pampa, Itaqui, Rio Grande do Sul (RS), Brazil (coordinates $29^{\circ} 09^{\prime} 21.68^{\prime \prime} \mathrm{S} ; 56^{\circ} 33^{\prime} 02.58^{\prime \prime} \mathrm{W}$, altitude $74 \mathrm{~m}$ ). According to the Brazilian Soil Classification System, the soil was classified as Kandic Plinthaquults (Embrapa, 2018) and, according to the climatic classification of Köppen, the climate of the region is of the Cfa-type, subtropical with no defined dry season (Kuinchtner \& Buriol, 2001).

The experiment was carried out in a completely randomized block design in a three-factor arrangement, $3 \times 2$ $\times 18$ (number of stems $\times$ row spacing $\times$ evaluations) in a splitplot design in time, where the spacing is the main plot, the number of stems is the subplot and the evaluations are the subsubplots. Each treatment consisted of four replications, each repetition represented by five plants, where the three central plants were evaluated. The spatial arrangements used were the spacing between rows of $3.0 \mathrm{~m}(6,666$ plants ha-1) and $1.5 \mathrm{~m}(13,333$ plants ha-1), keeping $0.5 \mathrm{~m}$ between plants for both treatments. The formation pruning consisted of maintaining 4, 6 and 8 stems per plant. The evaluations were performed weekly from the formation pruning.

To produce the seedlings, seeds were acquired from the commercial seed seller Sambalina Sementes. Sowing was carried out on October 24, 2017, in expanded polystyrene trays, containing 72 cells, with one seed per cell distributed at a depth of $0.4 \mathrm{~cm}$. The trays were placed on iron benches of one meter high and kept in a greenhouse, covered with transparent 120-micron polyethylene. Weather conditions were monitored throughout the experimental period using an automatic weather station located $50 \mathrm{~m}$ away from the experimental area (Figure 1). Seedling irrigation was carried out by manual irrigation twice a day.

In the planting area, $\mathrm{pH}$ correction was carried out according to the need for corrective material indicated by the soil analysis (Table 1 ). The fertilization recommendation was made using tomato culture as a base (Muniz et al., 2015; Rodrigues et al., 2018). The basic fertilization consisted of 20 $\mathrm{kg} \mathrm{ha}^{-1}$ of $\mathrm{N}, 230 \mathrm{~kg} \mathrm{ha}^{-1}$ of $\mathrm{P}_{2} \mathrm{O}_{5}$, and $40 \mathrm{~kg} \mathrm{ha}^{-1}$ of $\mathrm{K}_{2} \mathrm{O}$ in the forms of urea $(45 \% \mathrm{~N})$, triple superphosphate $\left(41 \% \mathrm{P}_{2} \mathrm{O}_{5}\right)$ and potassium chloride $\left(58 \% \mathrm{~K}_{2} \mathrm{O}\right)$, respectively. The topdressing fertilization consisted of $170 \mathrm{~kg} \mathrm{ha}^{-1}$ of $\mathrm{N}$ and $230 \mathrm{~kg} \mathrm{ha}^{-1}$ of $\mathrm{K}_{2} \mathrm{O}$, in the forms of urea and potassium chloride, respectively, which was divided into five applications, the first performed 40 days after transplanting and the others performed every 20 days.

Seedling transplanting was carried out at 80 days, in January 2018, when the plants had five expanded leaves, for five beds of $0.3 \mathrm{~m}$ in height, $0.6 \mathrm{~m}$ in width, and $30 \mathrm{~m}$ in length. The conduction system used was an espalier type, using support poles with $2.3 \mathrm{~m}$ length with galvanized wires fixed at 0.5 and $1.7 \mathrm{~m}$ from the ground, in which the stems were 


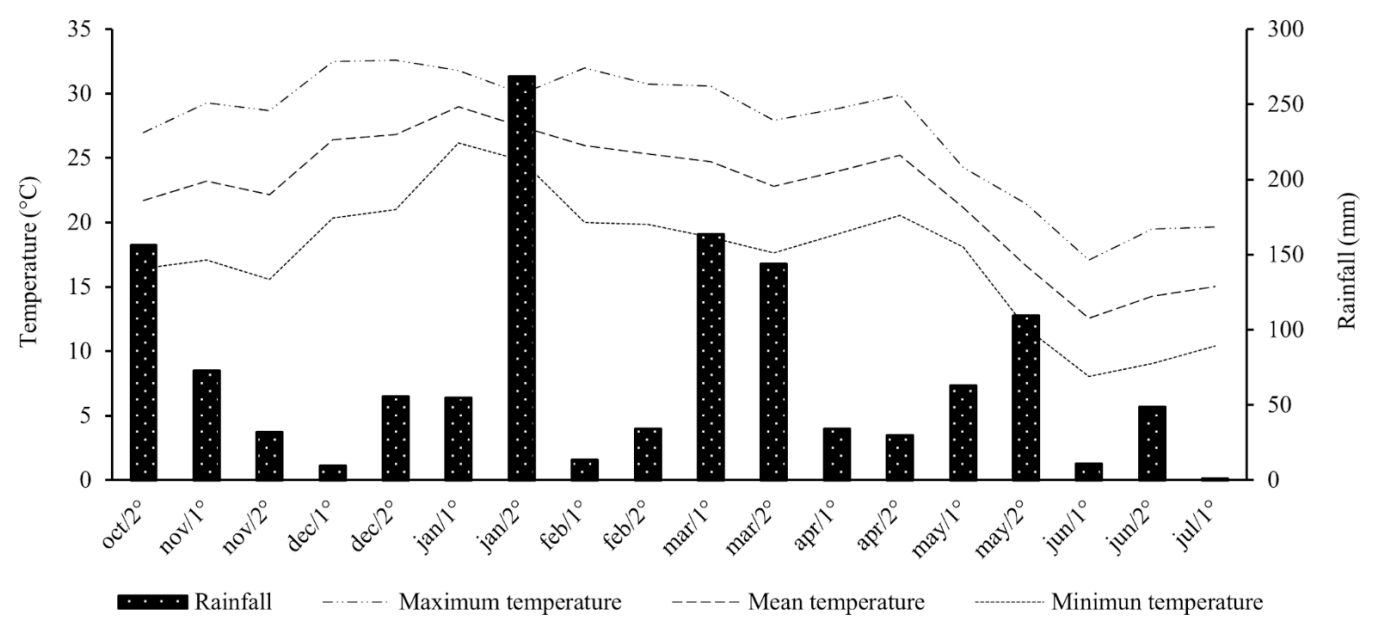

Figure 1. Maximum, mean and minimum air temperatures, and accumulated fortnightly rainfall, between October 2017 and July 2018.

Table 1. Soil chemical composition of the cultivation area.

\begin{tabular}{|c|c|c|c|c|c|c|c|c|c|c|c|}
\hline Clay & O.M. & v & \multirow{3}{*}{$\begin{array}{c}\begin{array}{c}\mathrm{pH} \\
\text { water }\end{array} \\
5.4\end{array}$} & \multirow{2}{*}{$\begin{array}{l}\text { Index } \\
\text { SMP }\end{array}$} & \multirow{2}{*}{\multicolumn{2}{|c|}{$\left(\mathrm{mg} \mathrm{dm}^{-3}\right)$}} & Al & $\mathrm{Ca}$ & $\mathrm{Mg}$ & $\mathrm{H}+\mathrm{Al}$ & \multirow{3}{*}{$\begin{array}{l}\text { CTC } \\
\text { pH7 } \\
10.8\end{array}$} \\
\hline & $(\%)$ & & & & & & \multicolumn{4}{|c|}{$\left(\mathrm{cmol}_{\mathrm{c}} \mathrm{dm}^{-3}\right)^{3}$} & \\
\hline 18 & 1.4 & 73 & & 6.4 & 4.1 & 30 & 0.1 & 5.6 & 2.2 & 2.9 & \\
\hline
\end{tabular}

tutored with plastic tape (Muniz et al., 2015). The conduction pruning was performed at 49 days after transplanting, after the plants had obtained the number of stems according to the desired conditions. Maintenance pruning, with the removal of basal and axillary shoots, was carried out weekly in order to maintain the number of recommended stems.

The evaluations consisted of determining height (HPS) and diameter (DPS) of the main stem, and total number of leaves per plant (NLE). Harvestings were performed at 100, 115, 130, 145 , and 160 days after transplanting (DAT), and from these, the number of fruits (NFR), average weight of fruit with calyx (AWFC), average weight of fruit without calyx (AWF), average weight of calyx (AWC), and the yields of fruits with calyx (PFC) and fruits without calyx (PF) were estimated.

The harvest point was determined following Colombian Technical Standard No. 4,580, 1999, of the Colombian Institute of Technical Standards, following the visual scale, when the fruit calyx displayed yellow-green, yellow, and brown-yellow colors. To measure HPS and DPS, a graduated ruler and a manual caliper were used, respectively. The height was obtained by measuring between the base of the plant and the bud located at the end of the tallest branch, and the stem diameter was obtained by measuring the thickest stem at 0.1 $\mathrm{m}$ from the ground. For the assessment of AWFC, AWF, and AWC, a precision scale was used.

The results were submitted to the analysis of normality, by the Shapiro-Wilk test, being transformed through the formula $\log (x)$ when they did not present a normal distribution and after this, the results were submitted to the analysis of homogeneity of variances by the test of Bartlett. After, the results were subjected to analysis of variance, and the means were compared using the test of Tukey at $5 \%$ probability. Regression was also performed, adjusting the equations to the data obtained, adopting the interaction by the significant
$\mathrm{F}$ test at $5 \%$ probability as a criterion for choosing the model. The results were also subjected to Principal Component Analysis using the Past ${ }^{\circ}$ program. Before the multivariate analysis, the data matrix was dimensioned for each variable to assume the same weight during the analysis (mean $=0$ and variation $=1$ ).

\section{Results and Discussion}

The evaluated factors influenced the dependent variables differently, being emphasized through the multivariate analysis (Figure 2). Together, the principal component one (PC I) (Figure 2A) and the principal component two (PC II) (Figure $2 \mathrm{~B})$, explained $80.78 \%$ of the total variation between the variables. While $\mathrm{PCI}$ infer the spacing effect, $\mathrm{PC}$ II distinguishes the influence of the number of stems on the growth and production of cape gooseberry. From these evaluations, there is an increase in height (HPS) and diameter of the main stem (DPS), also in average weight of calyx (AWC), and a reduction in yield as there is a reduction in the number of stems in plants cultivated in the spacing of $1.5 \mathrm{~m}$. Plants grown with a spacing of $3.0 \mathrm{~m}$ had a higher number of leaves (NLE), but this factor did not contribute to promoting a greater growth and yield.

A triple interaction was observed between row spacing, number of stems, and evaluations for HPS, NLE, AWFC, AWF, and AWC. For DPS, NFR, PFC, and PF an interaction was found between spacing $x$ number of stems.

The HPS showed a quadratic growth trend for the two spacing evaluated, regardless of the number of stems, with a more accelerated increase in stem height up to 119 DAT followed by a reduction in the expansion speed of the main stem (Figure 3). This behavior may have been caused by the climatic conditions, as high temperatures (approximately $30^{\circ} \mathrm{C}$ ) tend to promote vegetative growth, while in mild climate conditions 
A.

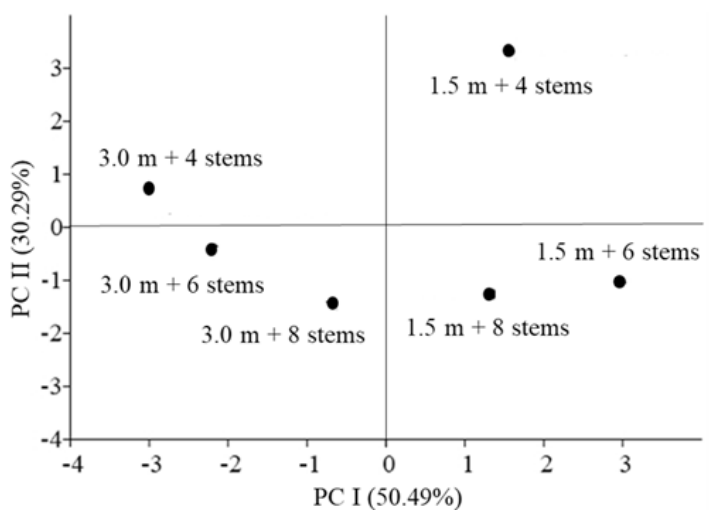

B.

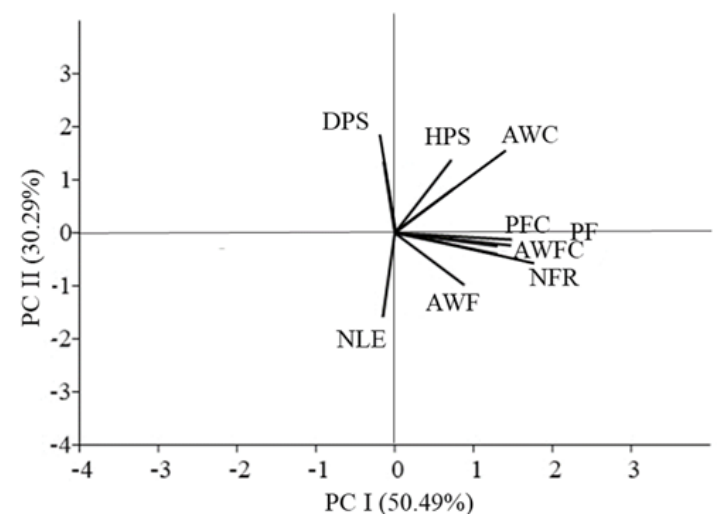

Figure 2. Analysis of the principal components between row spacing and number of stems (A) and the relationship with dependent variables (B), regarding height (HPS) and diameter of the main stem (DPS), number of leaves per plant (NLE), average weight of fruit with calyx (AWFC) and without calyx (AWF), total number of fruits (NFR), average weight of calyx (AWC) and yield of fruit with calyx (PFC) and without calyx (PF) of cape gooseberry.

A.

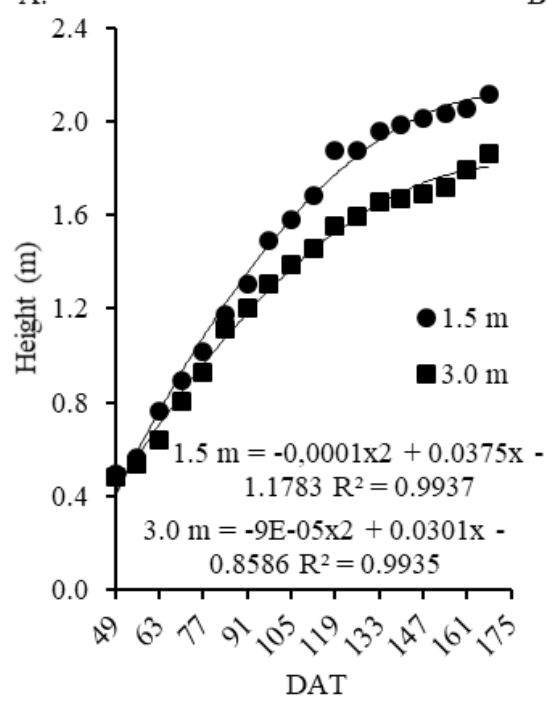

B.

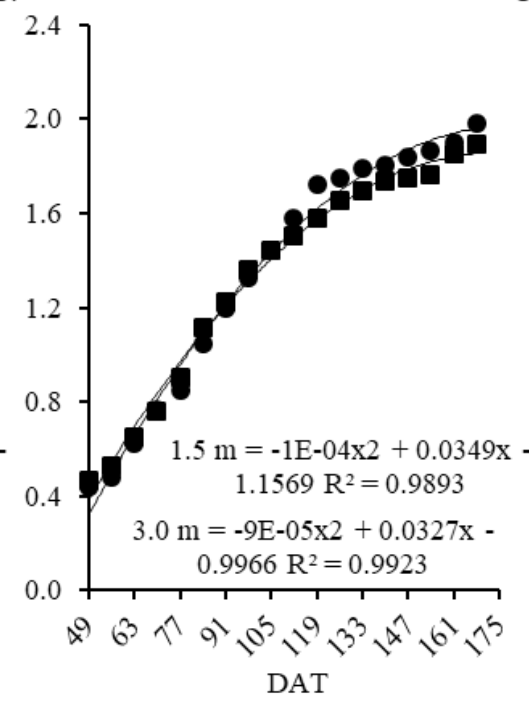

C.

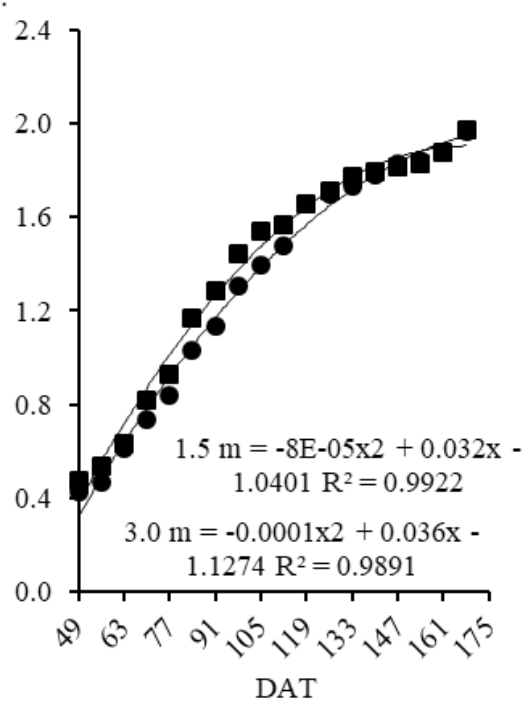

Figure 3. Height of main stem (HPS) of cape gooseberry, cultivated with 4 (A), 6 (B) and 8 stems (C) in the spacing of 1.5 and 3.0 $\mathrm{m}$ according to the days after transplanting (DAT).

(approximately $14{ }^{\circ} \mathrm{C}$ ), there is a stimulus to the emission and development of reproductive structures, contributing to the reduction of the plant cycle (Lima et al., 2010). In the present study, an average temperature of $21.9^{\circ} \mathrm{C}$ was observed (Figure 1), which contributed to the balanced plant growth throughout the cycle, although after 105 DAT (second half of April), the average temperature decreased progressively, which may have resulted in a reduction in the increase in the height of cape gooseberry stems. In addition, the reduction in growth speed from 119 DAT may be related to the plant's own phenology, as several studies report a reduction in the growth rate of cape gooseberry during the reproductive phase (Muniz et al., 2015; Rodrigues et al., 2018). From the beginning of the emission of flower buttons, part of the photosynthates are directed to the development of new reproductive structures, prioritizing the propagation of the species before the growth and vegetative development (Fischer et al., 2015).

The plants managed with 4 stems showed the highest HPS in the spacing of $1.5 \mathrm{~m}$ between rows in relation to the spacing of $3.0 \mathrm{~m}$ from the 105 DAT (Table 2). In plants with 6 stems, the spacing did not influence HPS, while in plants with 8 stems, at 91 and 105 DAT, the spacing of the $1.5 \mathrm{~m}$ induced less HPS. Probably, in plants managed with 8 stems and spacing of the $1.5 \mathrm{~m}$, competition for light, water and nutrients and even photosynthates was induced, resulting in lower growth compared to plants in less densified spacing. In adverse edaphoclimatic conditions, metabolic changes in the plant may result in stomatal closure, loss of turgor, reduction in transpiration and carbon accumulation, and, consequently, decreased or interrupted cell growth (Manoli et al., 2017).

A different situation occurred in plants with 4 stems and spaced at $1.5 \mathrm{~m}$, mainly due to the increase in the competition for light, which induced the plants to greater internode elongation and, consequently, resulted in taller plants. In light-deficient environmental conditions, stem elongation occurs so that basal and intermediate leaves can have access to light intensity and quality similar to 
Table 2. Height of main stem (HPS) of cape gooseberry conducted with different numbers of stems in spacings of 1.5 and $3.0 \mathrm{~m}$ according to the days after transplanting (DAT).

\begin{tabular}{|c|c|c|c|c|c|c|c|c|c|c|c|c|c|c|c|c|c|c|c|c|c|}
\hline \multirow{2}{*}{\multicolumn{2}{|c|}{ Treatments }} & \multicolumn{20}{|c|}{ DAT } \\
\hline & & \multicolumn{2}{|l|}{49} & \multicolumn{2}{|c|}{63} & \multicolumn{2}{|c|}{77} & \multicolumn{2}{|c|}{91} & \multicolumn{2}{|c|}{105} & \multicolumn{2}{|c|}{119} & \multicolumn{2}{|c|}{133} & \multicolumn{2}{|c|}{147} & \multicolumn{2}{|c|}{161} & \multicolumn{2}{|c|}{168} \\
\hline \multirow{2}{*}{4 stems } & $1.5 \mathrm{~m}$ & $0.49 *$ & $a$ & 0.76 & $a$ & 1.02 & $a$ & 1.30 & $a$ & 1.58 & $a$ & 1.87 & $a$ & 1.96 & $a$ & 2.01 & $a$ & 2.05 & $\mathrm{a}$ & 2.12 & $a$ \\
\hline & $3.0 \mathrm{~m}$ & 0.48 & $a$ & 0.64 & $a$ & 0.93 & $a$ & 1.20 & $a$ & 1.38 & $b$ & 1.55 & $b$ & 1.66 & $b$ & 1.69 & $b$ & 1.79 & $b$ & 1.86 & b \\
\hline \multirow{2}{*}{6 stems } & $1.5 \mathrm{~m}$ & 0.44 & $a$ & 0.62 & $a$ & 0.85 & $a$ & 1.20 & $a$ & 1.44 & a & 1.72 & $a$ & 1.79 & $a$ & 1.84 & $a$ & 1.90 & $\mathrm{a}$ & 1.98 & a \\
\hline & $3.0 \mathrm{~m}$ & 0.47 & a & 0.65 & a & 0.90 & $a$ & 1.23 & $a$ & 1.44 & a & 1.58 & $b$ & 1.70 & $a$ & 1.75 & a & 1.85 & a & 1.89 & a \\
\hline 8 stems & $1.5 \mathrm{~m}$ & 0.42 & $a$ & 0.62 & $a$ & 0.84 & $a$ & 1.13 & $b$ & 1.40 & $b$ & 1.66 & $\mathrm{a}$ & 1.73 & $a$ & 1.83 & $\mathrm{a}$ & 1.88 & $\mathrm{a}$ & 1.97 & a \\
\hline \multirow[t]{2}{*}{$1.5 \mathrm{~m}$} & 6 stems & 0.44 & $a$ & 0.62 & $a$ & 0.85 & $b$ & 1.20 & $a b$ & 1.44 & $a b$ & 1.72 & $b$ & 1.79 & $b$ & 1.84 & $b$ & 1.90 & $b$ & 1.98 & a \\
\hline & 8 stems & 0.42 & $a$ & 0.61 & $a$ & 0.84 & $b$ & 1.13 & $b$ & 1.40 & $b$ & 1.66 & $b$ & 1.73 & $b$ & 1.83 & $b$ & 1.88 & $b$ & 1.97 & a \\
\hline \multirow{3}{*}{$3.0 \mathrm{~m}$} & 4 stems & 0.48 & $a$ & 0.64 & $a$ & 0.93 & $a$ & 1.20 & $a$ & 1.38 & $b$ & 1.55 & $a$ & 1.66 & $a$ & 1.69 & $\mathrm{a}$ & 1.79 & $\mathrm{a}$ & 1.86 & a \\
\hline & 6 stems & 0.47 & $a$ & 0.65 & $\mathrm{a}$ & 0.90 & $a$ & 1.23 & $a$ & 1.44 & $a b$ & 1.58 & $\mathrm{a}$ & 1.70 & $a$ & 1.75 & $\mathrm{a}$ & 1.85 & $\mathrm{a}$ & 1.89 & a \\
\hline & 8 stems & 0.48 & $a$ & 0.63 & $a$ & 0.93 & $a$ & 1.28 & $a$ & 1.54 & $a$ & 1.66 & $a$ & 1.77 & $a$ & 1.82 & $a$ & 1.88 & $a$ & 1.97 & a \\
\hline
\end{tabular}

*Means followed by the same letter in the column do not differ from each other by the test of Tukey at $5 \%$ probability.

those found by the organs in the upper strata of the plant (Silva et al., 2016). A more uniform light condition increases stomatal and mesophilic conductance for the acquisition and assimilation of photosynthetic carbon and, thus, contributes to the increase in leaf photosynthesis and plant growth ( $\mathrm{Li}$ et al., 2019).

A marked increase was observed in DPS at 56 and 63 DAT, with gradual growth until the end of the cycle, resulting in a cubic trend (Figure 4). Cape gooseberry presents a high increase in the thickness of the stem up to approximately 60 DAT and, as the plant grows and develops, the diameter of the stems tends to increase; however, more gradually than the height of the plant (Muniz et al., 2015). The change in stem thickness is caused by the changes that occur throughout the plant cycle, which promote the change from primary to secondary growth, resulting in the thickening of the stem for the deposition of new tissues and translocation of solutes, which is later directed for the subsistence of reproductive structures (Rodrigues et al., 2018).

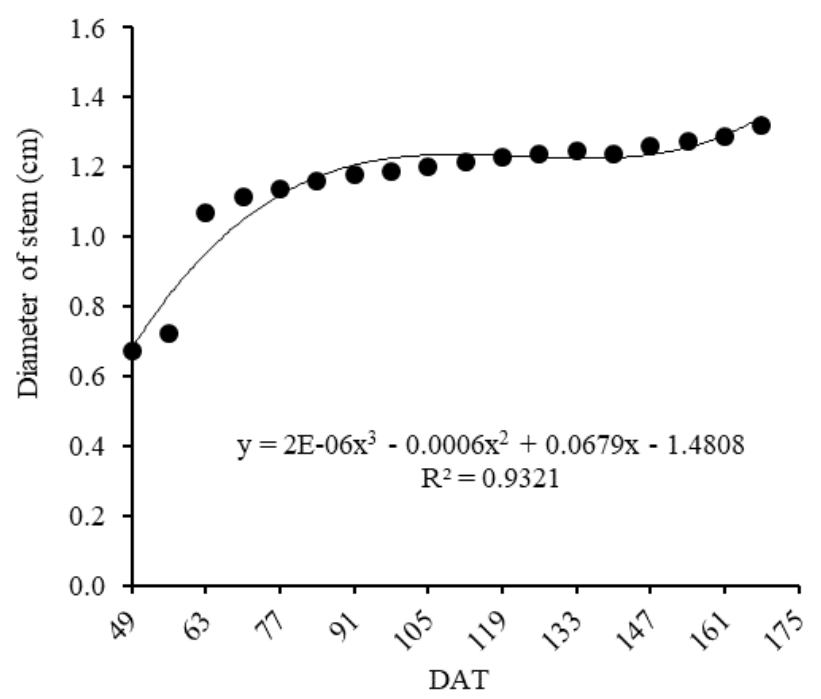

Figure 4. Diameter of main stem (DPS) of cape gooseberry cultivated in the 1.5 and $3.0 \mathrm{~m}$ spacing and with 4,6 or 8 stems throughout the days after transplanting (DAT).
An increase was observed in the DPS as the number of stems was reduced, regardless of the spacing used, with plants conducted with 4 stems showing a larger diameter in denser spacing, while the opposite situation was found in plants with 8 stems (Table 3 ). In studies evaluating the effect of plant spacing and conduction systems, Muniz et al. (2015) found an increase in diameter as the number of stems decreased, and there were no differences in the diameter of the stems with the change in spacing for plants conducted in the espalier type. The stem diameter shows a greater capacity for transporting solutes through the vascular tissue of the plant, which suggests that despite of having fewer leaves, plants conducted with 4 stems (Table 4) present greater transport of solutes for the subsistence of vegetative structures and for fruit growth and development (Mezzalira et al., 2017).

For the NLE, all spacings and number of stems adjusted to the cubic regression model during the evaluated period (Figure 5). There was an accelerated increase in NLE in the first weeks after formation pruning, with a peak between 84 and 105 DAT. After this period, there was a reduction in the NLE, following the decrease in average temperature (Figure 1 ) and the beginning of the reproductive period. These results corroborate those of Rodrigues et al. (2013), when evaluating the phenology of cape gooseberry in a greenhouse, in which a decrease was observed in the number of leaves as the temperature decreased, due to the sensitivity of the plant to the cold weather. Similar results were also obtained by Rodrigues et al. (2018), who found the largest number of leaves at 105 DAT, followed by a decrease, but associated the

Table 3. Diameter $(\mathrm{cm})$ of the main stem (DPS) of cape gooseberry cultivated with 4, 6 and 8 stems in the spacing of 1.5 and $3.0 \mathrm{~m}$ between rows.

\begin{tabular}{cccc}
\hline \multirow{2}{*}{ Spacing } & \multicolumn{3}{c}{ Number of stem } \\
\cline { 2 - 4 } & $\mathbf{4}$ & $\mathbf{6}$ & $\mathbf{8}$ \\
\hline $1.5 \mathrm{~m}$ & $1.23 \mathrm{Aa}^{*}$ & $1.13 \mathrm{Ba}$ & $1.09 \mathrm{Cb}$ \\
$3.0 \mathrm{~m}$ & $1.18 \mathrm{Ab}$ & $1.14 \mathrm{Ba}$ & $1.15 \mathrm{Ba}$ \\
$\mathrm{CV}(\%)$ & \multicolumn{4}{c}{4.46} \\
\hline
\end{tabular}

* Means followed by the same capital letter in the rows and by the lower case in the columns do not differ from each other by the test of Tukey at $5 \%$ probability. 
A.

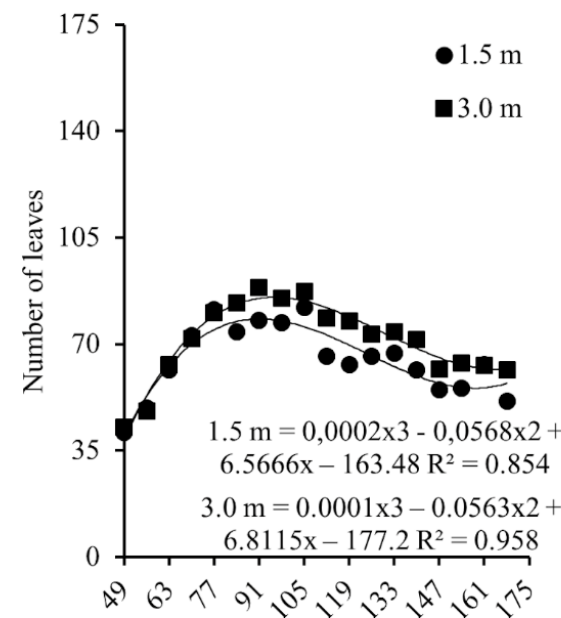

DAT
B.

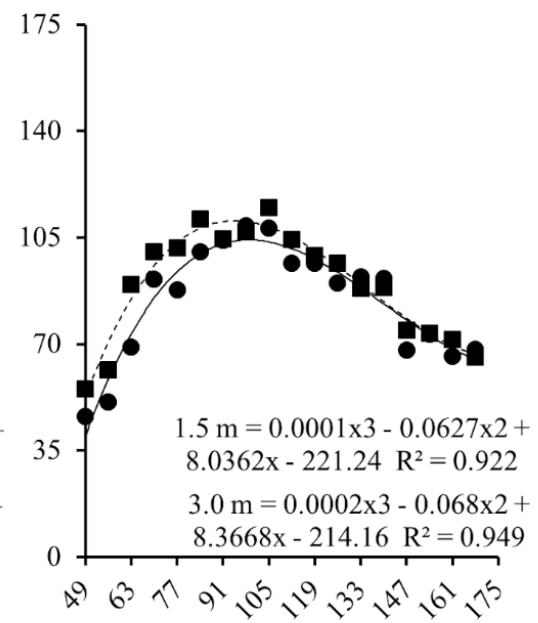

DAT
C.

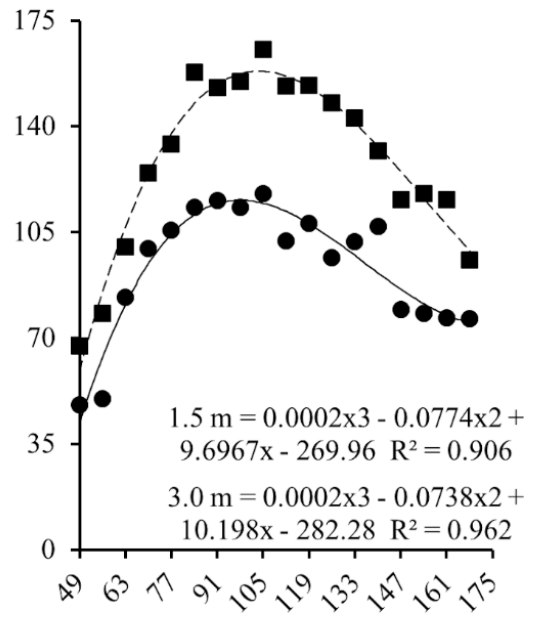

DAT

Figure 5. Number of leaves per plant (NLE) of cape gooseberry cultivated with 4 (A), 6 (B) e 8 stems (C) in the spacing of 1.5 and $3.0 \mathrm{~m}$ according to the days after transplanting (DAT).

senescence of the leaves with the increase in the translocation of photosynthates for fruit formation and maturation. Therefore, in the present study, both situations occurred, which may have contributed synergistically to the increase in the senescence of the leaves, and consequently, contributed to the reduction in the plant cycle.

The plants conducted with 8 stems showed the highest means for NLE in both spacings (Table 4). This result may be due to the number of apical meristems per plant, since plants with 8 stems have a greater number of stems which may imply in a greater number of meristems. According to Lian \& Cock (1979), plants with a greater number of meristems result in a greater number of leaves and leaf area. This finding also corroborates the results obtained by Streck et al. (2014), as in a work evaluating the density of cassava plants, obtained an increase in the number of leaves and leaf area as the number of stems increased, and the leaf dimensions decreased as the structures and the number of stems per plant increased. Thus, in the present study, there was an increase in the number of leaves as the number of stems increased.
Also, plants conducted with 4 and 6 stems showed little effect of spacing on NLE throughout the cycle, while on plants with 8 stems there was a greater NLE in the 3.0-m spacing during all evaluations, not differing at 63 and 133 DAT from plants grown at $1.5-\mathrm{m}$ spacing. The smaller number of leaves in the $1.5 \mathrm{~m}$ spacing may be related to the lower growth of plants with 8 stems due to competition stress. In stressful situations, the plant reduces the leaf emission to balance its source/sink ratio, since young leaves, because of their low contribution to photosynthates, present a considerable expenditure of energy when acting as a sink (Fischer et al., 2012).

Few studies in the literature evaluate the effect of spacing and number of stems on cape gooseberry leaf emission. D'Angelo et al. (2017) evaluated the effect of pruning on the growth and production of cape gooseberry and observed the largest leaf area in non-pruned plants. In addition, even though the leaves are not the major plant structure of interest for commercialization of cape gooseberry, several studies report the beneficial properties of leaves for the human

Table 4. Number of leaves per plant (NLE) of cape gooseberry cultivated with different number of stems in spacing of 1.5 and $3.0 \mathrm{~m}$ according to the days after transplanting (DAT).

\begin{tabular}{|c|c|c|c|c|c|c|c|c|c|c|c|c|c|c|c|c|c|c|c|c|c|}
\hline \multirow{2}{*}{\multicolumn{2}{|c|}{ Treatments }} & \multicolumn{20}{|c|}{ DAT } \\
\hline & & \multicolumn{2}{|c|}{49} & \multicolumn{2}{|c|}{63} & \multicolumn{2}{|c|}{77} & \multicolumn{2}{|c|}{91} & \multicolumn{2}{|c|}{105} & \multicolumn{2}{|c|}{119} & \multicolumn{2}{|c|}{133} & \multicolumn{2}{|c|}{147} & \multicolumn{2}{|c|}{161} & \multicolumn{2}{|c|}{168} \\
\hline \multirow{2}{*}{4 stems } & $1.5 \mathrm{~m}$ & 41 & $a$ & 62 & $a$ & 81 & $a$ & 78 & $b$ & 82 & $a$ & 63 & $\mathrm{~b}$ & 67 & $a$ & 55 & $a$ & 63 & $a$ & 51 & $\mathrm{~b}$ \\
\hline & $3.0 \mathrm{~m}$ & 43 & $a$ & 63 & $\mathrm{a}$ & 80 & a & 89 & a & 87 & $a$ & 78 & $\mathrm{a}$ & 74 & a & 62 & $a$ & 63 & a & 62 & $\mathrm{a}$ \\
\hline 6 stems & $3.0 \mathrm{~m}$ & 55 & $a$ & 90 & $a$ & 102 & a & 105 & a & 115 & $a$ & 99 & $a$ & 88 & $a$ & 75 & $\mathrm{a}$ & 72 & a & 66 & a \\
\hline 8 stems & $1.5 \mathrm{~m}$ & 48 & $b$ & 84 & $b$ & 106 & $b$ & 116 & $b$ & 118 & $b$ & 108 & $b$ & 102 & $b$ & 79 & b & 77 & $b$ & 76 & b \\
\hline \multirow[t]{2}{*}{$1.5 \mathrm{~m}$} & 6 stems & 46 & $a$ & 69 & b & 88 & $b$ & 104 & $b$ & 108 & $a$ & 97 & $b$ & 92 & $a$ & 68 & b & 66 & $a b$ & 68 & a \\
\hline & 8 stems & 48 & $\mathrm{a}$ & 84 & $a$ & 106 & a & 116 & $a$ & 118 & $a$ & 108 & $\mathrm{a}$ & 102 & $a$ & 79 & $a$ & 77 & $a$ & 76 & $a$ \\
\hline \multirow{3}{*}{$3.0 \mathrm{~m}$} & 4 stems & 43 & C & 63 & $b$ & 80 & C & 89 & C & 87 & $c$ & 78 & C & 74 & C & 62 & C & 63 & $b$ & 62 & b \\
\hline & 6 stems & 55 & $b$ & 90 & a & 102 & $b$ & 105 & $b$ & 115 & $b$ & 99 & $b$ & 88 & $b$ & 75 & b & 72 & $b$ & 66 & b \\
\hline & 8 stems & 67 & $a$ & 100 & $a$ & 134 & a & 153 & $a$ & 166 & $a$ & 154 & $a$ & 143 & $a$ & 116 & $a$ & 116 & a & 96 & a \\
\hline CV (\%) & & \multicolumn{20}{|c|}{3.83} \\
\hline
\end{tabular}

*Means followed by the same letter in the column do not differ from each other by the test of Tukey at $5 \%$ probability. 
organism, such as the presence of antioxidants and phenolic compounds (Çakir et al., 2014). Therefore, the knowledge of the dynamics of leaf emission on cape gooseberry is relevant both to understanding the plant growth and development and for possible uses in human food.

The fruits reached the harvest point at 100 DAT, with five harvests being carried out until 160 days (Figure 6). A cubic trend was observed throughout the harvests for AWFC and AWF, increasing until 115 DAT for plants with 4 stems, with a subsequent reduction to 145 DAT followed by a further increase in the last harvest (Figures $6 A$ and $6 D$ ). In plants with 6 and 8 stems, the maximum values were obtained at 130 DAT followed by a decrease until the end of harvests (Figure 6B, $6 \mathrm{C}, 6 \mathrm{E}$, and $6 \mathrm{~F}$ ). The reduction in the average weight in the last harvests may be associated with the decrease in the leaves number (Figure 5) and low temperatures (Figure 1), as the plants had already characterized the senescence stage.

Due to the indeterminate growth habit of cape gooseberry plants, the initial stages of the reproductive period need an increasing demand of metabolites for the subsistence and emission of young vegetative structures and for the formation of reproductive structures, which are presented as receptor structures (Fischer et al., 2015). However, in the final stages of the cycle, there is a defoliation (Figure 5), which reduces the relationship between synthesis structures and receptor structures, so there is a reduction in the photosynthates necessary for the maintenance and growth of the plant and fruit. In tomato plants, as defoliation occurs, besides reducing reproductive efficiency, the fruit number and weight are constantly reduced, which is explained by the change in the source/sink ratio with less accumulation of photosynthates available for emission and maintenance of reproductive structures (Islam et al., 2016).

It was observed that the spacing differed only for plants conducted with 6 stems for AWFC and AWF and for plants with 4 stems for AWC, with higher values in plants grown at $1.5 \mathrm{~m}$ spacing (Table 5). The average weight of the fruits and the calyx were not affected as the number of stems
A

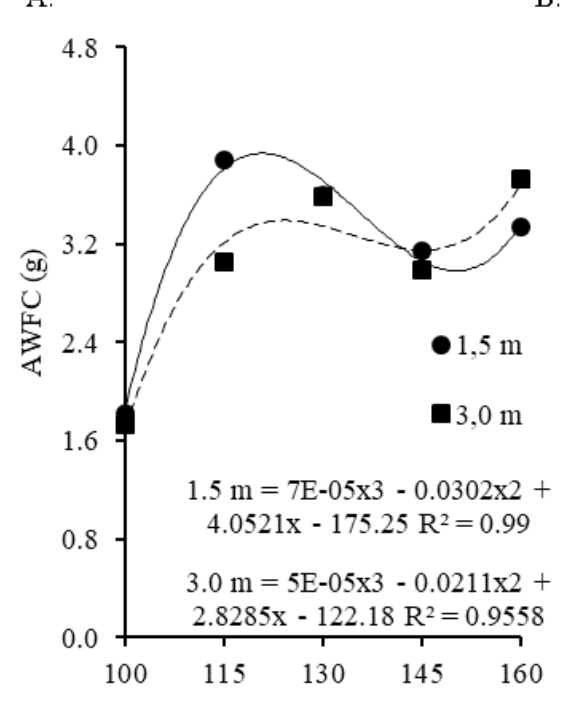

B.
C.
D.

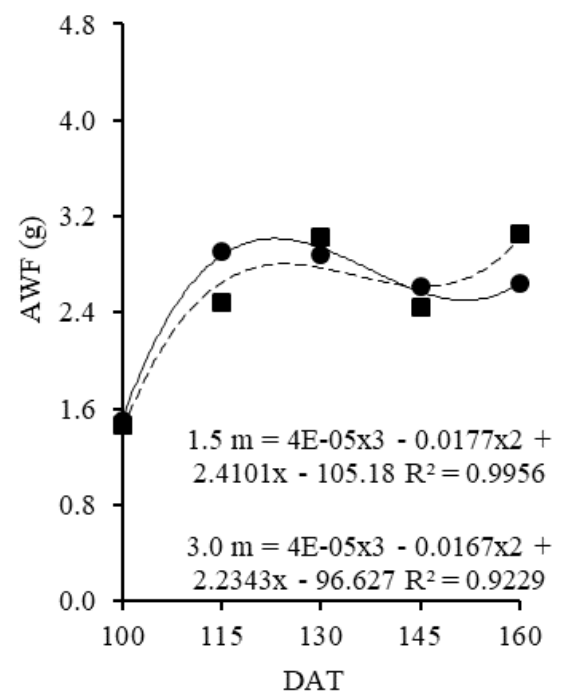

E.

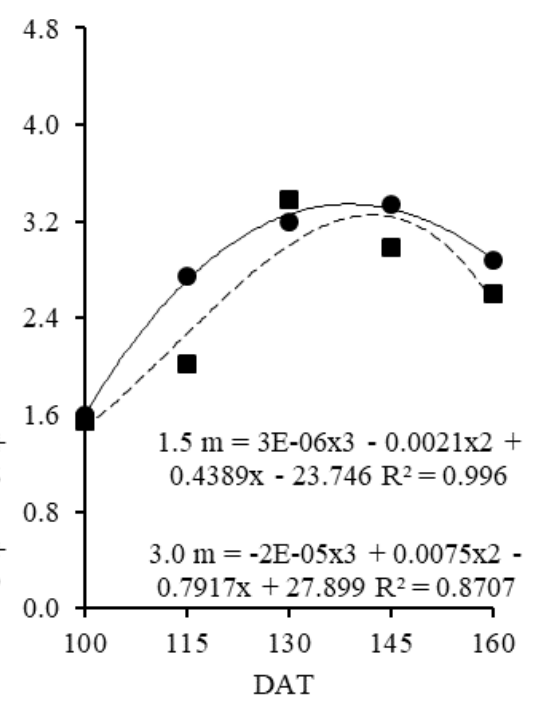

F.

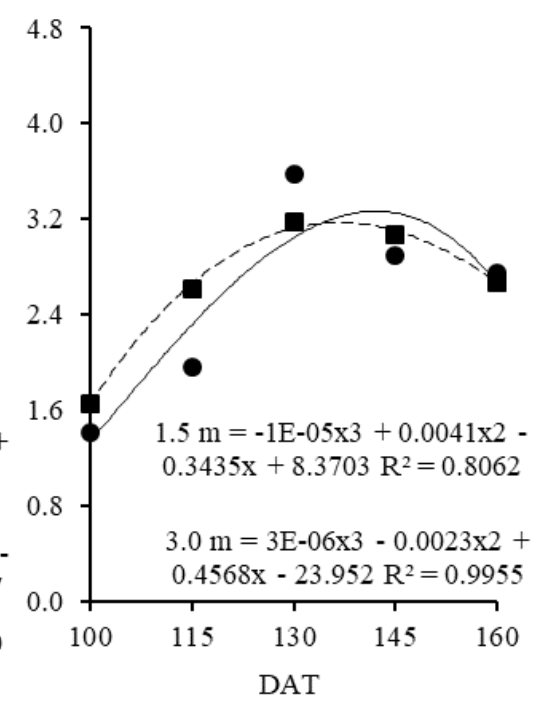

Figure 6. Average weight of fruits with calyx (AWFC) and without calyx (AWF) of cape gooseberry cultivated with 4 (A, D), 6 (B, E) and 8 stems (C, F) throughout harvests in days after transplanting (DAT). 
Table 5. Average weight of fruit with (AWFC) and without calyx (AWF), and average weight of calyx (AWC) of cape gooseberry cultivated with 4, 6 and 8 stems per plant in the spacing of 1.5 and $3.0 \mathrm{~m}$ between rows.

\begin{tabular}{|c|c|c|c|c|c|c|c|c|c|}
\hline \multirow{3}{*}{ Spacing } & \multicolumn{9}{|c|}{ Number of stem } \\
\hline & 4 & 6 & 8 & 4 & 6 & 8 & 4 & 6 & 8 \\
\hline & \multicolumn{3}{|c|}{ AWFC (g) } & \multicolumn{3}{|c|}{ AWF (g) } & \multicolumn{3}{|c|}{ AWC (g) } \\
\hline $1.5 \mathrm{~m}$ & $3.16 \mathrm{Aa}$ & $3.34 \mathrm{Aa}$ & $3.09 \mathrm{Aa}$ & $2.51 \mathrm{Ba}$ & $2.75 \mathrm{Aa}$ & $2.52 \mathrm{ABa}$ & $0.65 \mathrm{Aa}$ & $0.59 \mathrm{Aa}$ & $0.57 \mathrm{Aa}$ \\
\hline $3.0 \mathrm{~m}$ & $3.01 \mathrm{Aa}$ & $3.02 \mathrm{Ab}$ & $3.14 \mathrm{Aa}$ & $2.49 \mathrm{Aa}$ & $2.50 \mathrm{Ab}$ & $2.64 \mathrm{Aa}$ & $0.52 \mathrm{Ab}$ & $0.52 \mathrm{Aa}$ & $0.50 \mathrm{Aa}$ \\
\hline CV (\%) & \multicolumn{3}{|c|}{11.36} & \multicolumn{3}{|c|}{12.16} & \multicolumn{3}{|c|}{25.72} \\
\hline
\end{tabular}

*Means followed by the same capital letter in the rows and by the lower case in the columns do not differ from each other by the test of Tukey at $5 \%$ probability.

changed regardless of the spacing used. In a study evaluating the spatial arrangements of $3.0 \times 1.0$ and $3.0 \times 0.5 \mathrm{~m}$, Moura et al. (2016) did not find effect of spacing between plants on the average weight of fruit, with average values of $2.5 \mathrm{~g}$, but found a reduction in the weight fruit as the number of stems increased. On the other hand, D'Angelo et al. (2017) when evaluating the effect of pruning on cape gooseberry cultivation, also found no difference in the average weight of fruit between pruned plants.

The AWC showed a cubic trend over the harvests, with the highest values obtained at 115, 130, and 160 DAT for plants with 4, 8, and 6 stems, respectively (Figure 7). Lima et al. (2012), when evaluating physical and chemical characters of cape gooseberry fruits over the cultivation period, observed that as the weight of the fruit increased, the calyx weight also increased. While the levels of non-structural carbohydrates are low in the calyx and in the fruit of cape gooseberry, the concentration of sucrose in the calyx is accentuated in the same way as the levels found in the fruit (Fischer et al., 2015). Thus, although the calyx appears morphologically and anatomically similar to the leaf, its physiology is closely related to the fruit. This result is relevant for the producers, because although the calyx contributes to extend the period of storage and commercialization of the fruits, in some situations the cape gooseberry is commercialized without the calyx (Olivares-Tenorio et al., 2017). Therefore, the calyx becomes a waste during the processing of the fruit for commercialization, and with the increase in AWC, the costs for the waste disposal are also increased.

The NFR increased as the number of stems increased and the spacing was reduced (Table 6). The highest values in relation to the spacing were obtained with $1.5 \mathrm{~m}$ between rows, regardless of the number of stems, with average increases of $106 \%$ of the number of fruits per hectare in plants conducted in the spacing of $1.5 \mathrm{~m}$ in relation to those cultivated in $3.0 \mathrm{~m}$ between rows. The plants with 8 stems produced an average of 13 and $47 \%$ more fruit compared to plants with 6 and 4 stems, respectively. The emission of fruits in cape gooseberry occurs at the plant nodes $t$, with each node developing a vegetative and a reproductive bud (Rodrigues et al., 2013). As a result, plants with 8 stems, in addition to having a greater number of leaves (Table 4), also presented a higher number of fruits.

Different results were obtained by Moura et al. (2016), who found no effect of the number of stems on the number of fruits on cape gooseberry plants conducted with 2 and 4 stems. However, D'Angelo et al. (2017) observed an average increase of $353 \%$ in the number of fruits in non-pruned plants in relation to plants where formation pruning was performed. In addition, the increase in the number of fruits did not result in a reduction in the fruit average weight (Table 5), as found in some studies (Candian et al., 2017; Mourão et
A.

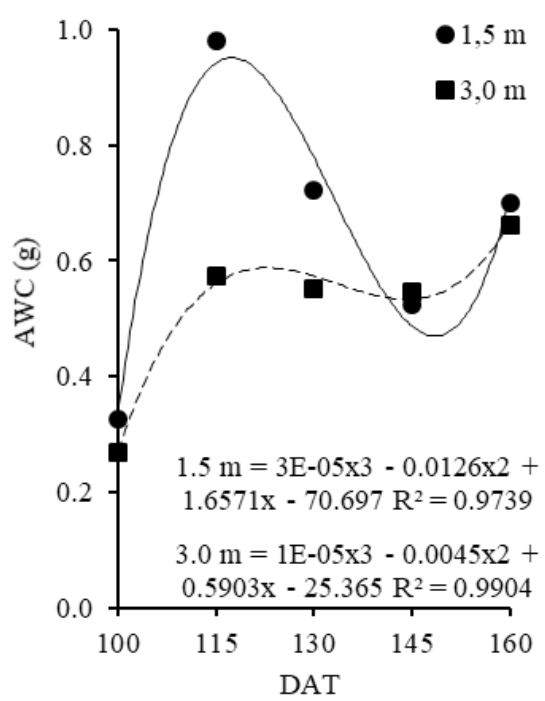

B.

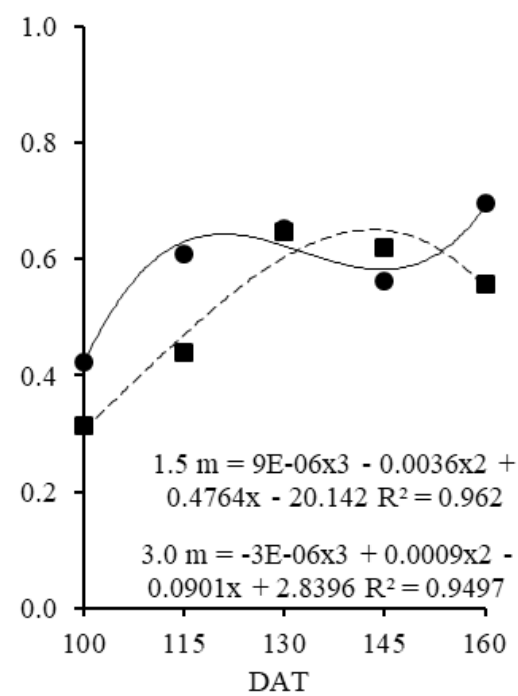

C.

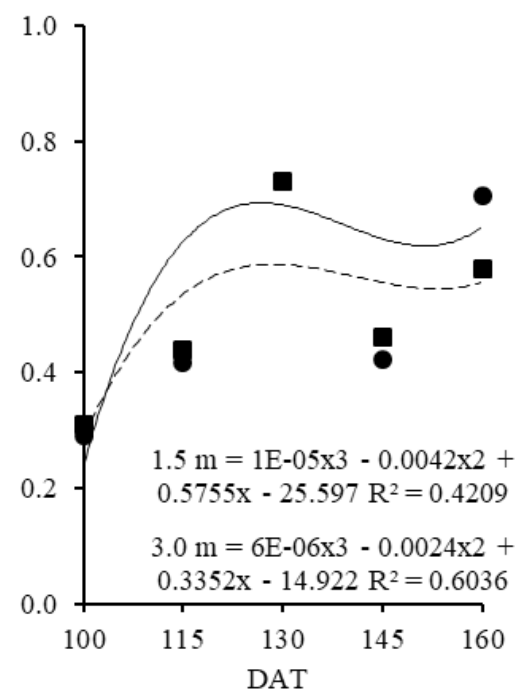

Figure 7. Average weight of calyx (AWC) of cape gooseberry cultivated with 4 (A), 6 (B) and 8 stems (C) throughout harvests in days after transplanting (DAT). 
Table 6. Estimation of the number of fruits (NFR), yield of fruit with calyx (PFC), yield of fruit without calyx (PF) of cape gooseberry cultivated with 4, 6 and 8 stems per plant cultivated in 1.5 spacing $\left(13,333 \mathrm{pl} \mathrm{ha}^{-1}\right)$ and $3.0 \mathrm{~m}\left(6,666 \mathrm{pl} \mathrm{ha}^{-1}\right)$ between rows.

\begin{tabular}{|c|c|c|c|c|c|c|c|c|c|}
\hline \multirow{3}{*}{ Spacings } & \multicolumn{9}{|c|}{ Number of stems } \\
\hline & 4 & 6 & 8 & 4 & 6 & 8 & 4 & 6 & 8 \\
\hline & \multicolumn{3}{|c|}{ NFR (thousand ha-1) } & \multicolumn{3}{|c|}{$\operatorname{PFC}\left(\mathrm{t} \mathrm{ha}^{-1}\right)$} & \multicolumn{3}{|c|}{ PF (t ha $\left.{ }^{-1}\right)$} \\
\hline $1.5 \mathrm{~m}$ & $501 \mathrm{Ba}^{*}$ & $647 \mathrm{Aa}$ & $716 \mathrm{Aa}$ & $1.84 \mathrm{Aa}$ & $2.27 \mathrm{Aa}$ & $2.33 \mathrm{Aa}$ & $1.42 \mathrm{Aa}$ & $1.80 \mathrm{Aa}$ & $1.89 \mathrm{Aa}$ \\
\hline $3.0 \mathrm{~m}$ & $233 \mathrm{Bb}$ & $307 \mathrm{Ab}$ & $363 \mathrm{Ab}$ & $0.79 \mathrm{Bb}$ & $0.95 \mathrm{ABb}$ & $1.16 \mathrm{Ab}$ & $0.67 \mathrm{Bb}$ & $0.78 \mathrm{ABb}$ & $1.00 \mathrm{Ab}$ \\
\hline CV (\%) & \multicolumn{3}{|c|}{0.98} & \multicolumn{3}{|c|}{2.51} & \multicolumn{3}{|c|}{2.49} \\
\hline
\end{tabular}

* Means followed by the same capital letter in the rows and by the lower case in the columns do not differ from each other by the test of Tukey at $5 \%$ probability.

al., 2017). In this sense, producers can conduct plants with 8 stems without affecting the dimensional characteristics of the fruit, increasing the profitability of cultivation according to the number of fruit, because even though the largest fruit is intended mainly for decorating sweets, cakes, and savory dishes, in cape gooseberry there is no price differentiation in relation to the product quality (D'Angelo et al., 2017).

Yield showed a similar behavior to the number of fruits, showing an increase in PFC and PF as the number of stems and plant density increased (Table 6). The highest yield was obtained in plants with $1.5 \mathrm{~m}$ between rows, regardless of the number of stems conducted, with an average increase of 108 and $122 \%$ in relation to the $3.0 \mathrm{~m}$ spacing between rows for fruits with and without calyx, respectively. However, there were no significant differences between the number of stems on the yield in plants grown with $1.5 \mathrm{~m}$ between rows, while for plants grown in the $3.0 \mathrm{~m}$ spacing, the highest yield of fruit with and without calyx were obtained in plants with 8 stems, with mean values higher than 22 and $47 \%$ for PFC and 28 and $49 \%$ for $\mathrm{PF}$ in relation to plants with 6 and 4 stems, respectively. These results have a very important practical effect. Producers who intend to intervene in a mechanized way, with a tractor unit in the crop production, should use the $3.0 \mathrm{~m}$ spacing with 8 stems to optimize yield. However, if mechanization is not necessary, the $1.5 \mathrm{~m}$ spacing results in higher yield.

These results also corroborate those obtained by Criollo et al. (2014) when evaluating the yield of three cape gooseberry genotypes. The authors found an increase of up to $120 \%$ on yield in plants with 8 stems compared to plants carried out with 4 stems. D'Angelo et al. (2017) evaluated the production of cape gooseberry in a system with and without pruning and did not obtain any difference between the number of stems defined by pruning for fruits per plant and yield. However, differently from this study, these authors found that plants with a greater number of stems produced fruits with a lower weight, which may limit the commercialization of fruits to certain markets.

Moura et al. (2016) found a yield of $10,910 \mathrm{~kg} \mathrm{ha}^{-1}$ using the spatial arrangement of $3.0 \times 0.5 \mathrm{~m}$, but with a longer harvest period. The culture cycle is limited by low temperatures (Figure 1), as temperatures below $14{ }^{\circ} \mathrm{C}$ stimulate the emission of reproductive organs and the culture cycle tends to be shorter (Lima et al., 2010). Thus, the yield obtained in this experiment can be explained by the short production time in relation to the other regions, since in tropical regions, the plants are cultivated for up to two years, whereas in regions of mild temperature, the cultivation is limited to eight months (Muniz et al., 2014).

\section{Conclusions}

The plants conducted with 4 stems showed the largest stem diameter and highest height in the $1.5 \times 0.5 \mathrm{~m}$ spacing, while the number of leaves, fruits and yield increased as the number of stems increased.

The vegetative and reproductive parameters were changed throughout the cape gooseberry plants cycle. The plants showed a gradual growth in height and diameter of the stem, with the highest values obtained at 168 DAT, even though the number of leaves decreased from 105 DAT with the reduction of temperatures and the beginning of production. The harvests started at 100 DAT and lasted until 160 DAT, and the number of stems did not affect the average weight of fruit and the calyx.

The highest estimated yield was achieved in the spacing of $1.5 \mathrm{~m}$ between rows, regardless of the number of stems conducted, with average values of $2.15 \mathrm{t} \mathrm{ha}^{-1}$ for fruits with calyx and $1.70 \mathrm{t} \mathrm{ha}^{-1}$ for fruits without calyx. For the spacing of $3.0 \mathrm{~m}$ between rows, plants with 8 stems showed the highest yield without impact on the fruit average weight.

\section{Compliance with Ethical Standards}

Funding: The authors grateful to the Universidade Federal do Pampa for providing the physical support for the study, as well as the Programa de Educação Tutorial - PET for the scholarship of the second author.

Conflict of interest: The authors declare no conflict of interest. The founding sponsors had no role in the design of the study; in the collection, analyses, or interpretation of data; in the writing of the manuscript, and in the decision to publish the results.

Author contribution: Conceptualization: AW, FJS, AOB, $A S M, M G B$; Data curation: AW, FJS, AOB; Formal analysis: $A W$, FJS, AOB; Funding acquisition: AW, FJS, $A O B, A S M, M G B$; Investigation: $F J S, A O B, A S M, M G B$; Methodology: AW, FJS, $A O B, A S M, M G B$; Project administration: AW; Resources: AW, FJS, $A O B, A S M, M G B$; Supervision: AW; Validation: AW, FJS, $A O B, A S M, M G B$; Visualization: AW, FJS, AOB, ASM, MGB; Writing - original draft: $F J S, A O B$; Writing - review \& editing: AW, FJS, AOB, ASM, MGB. 


\section{Literature Cited}

Bendlin, L.; Senff, C.O.; Kudlawicz-Franco, C.; Souza, A.; Da Veiga, C.P. Agribusiness management of Physalis peruviana L. fruit in Brazil. Bulgarian Journal of Agricultural Science, v.22, n.5, p.691-704, 2016. https://www.agrojournal.org/22/05-01.pdf. 01 Oct. 2020.

Çakir, Ö.; Pekmez, M.; Çepni, E.; Candar, B.; Fidan, K. Evaluation of biological activities of Physalis peruviana ethanol extracts and expression of $\mathrm{Bcl}-2$ genes in HeLa cells. Food Science and Technology, v.34, n.2, p.422-430, 2014. https://doi.org/10.1590/ fst.2014.0060.

Candian, J.S.; Martins, B.N.M.; Cardoso, A.I.I.; Evangelista, R.M.; Fujita, E. Stem conduction systems effect on the production and quality of mini tomato under organic management. Bragantia, v.76, n.2, p.238-245, 2017. https://doi.org/10.1590/1678-4499.558.

Criollo, H.; Lagos, T.C.; Fischer, G.; Mora, L.; Zamudio, L. Comportamiento de tres genotipos de uchuva (Physalis peruviana L.) bajo diferentes sistemas de poda. Revista Colombiana de Ciencias Hortícolas, v.8, n.1, p.34-43, 2014. https://doi. org/10.17584/rcch.2014v8i1.2798.

D’Angelo, J.W.O.; Bastos, M.C.; Cuquel, F.L. Maintenance pruning in physalis commercial production. Bragantia, v.76, n.2, p.214-219, 2017. https://doi.org/10.1590/1678-4499.128.

Empresa Brasileira de Pesquisa Agropecuária - Embrapa. Sistema brasileiro de classificação de solos. 5.ed. Rio de Janeiro: Embrapa, 2018. 356p.

Fischer, G.; Almanza-Merchán, P.J.; Ramírez, F. Source-sink relationships in fruit species. Revista Colombiana de Ciencias Hortícolas, v.6, n.2, p.238-253, 2012. https://doi.org/10.17584/ rcch.2012v6i2.1980.

Fischer, G.; Ulrichs, C.; Ebert, G. Contents of non-structural carbohydrates in fruiting cape gooseberry (Physalis peruviana L.) plants. Agronomía Colombiana, v.33, n.2, p.155-163, 2015. https://doi.org/10.15446/agron.colomb.v33nv33n2.51546.

Islam, A.F.M.S.; Haque, M.D.M.; Tabassum, R.; Islam, M.D.M. Effect of defolation on growth and yield response in two tomato (Solanum lycopersicum Mill.) varieties. Journal of Agronomy, v.15, n.2, p.68-75, 2016. https://doi.org/10.3923/ja.2016.68.75.

Kuinchtner, A.; Buriol, G.A. Clima do Estado do Rio Grande do Sul segundo a classificação climática de Köppen e Thornthwaite. Disciplinarum Scientia, v.2, n.1, p.171-182, 2001. https:// periodicos.ufn.edu.br/index.php/disciplinarumNT/article/ viewFile/1136/1077. 01 Oct. 2020.

Li, Q.; Liu, Y.; Tian, S.; Liang, Z.; Li, S.; Li, Y.; Wei, M.; Zhang, D. Effect of supplemental lighting on water transport, photosynthetic carbon gain and water use efficiency in greenhouse tomato. Scientia Horticulturae, v.256, e108630, 2019. https://doi.org/10.1016/j. scienta.2019.108630.

Lian, T.S.; Cock, J.H. Branching habit as a yield determinant in cassava. Field Crops Research, v.2, p.281-289, 1979. https://doi. org/10.1016/0378-4290(79)90029-7.

Lima, C.S.M.; Galarça, S.P.; Betemps, D.L.; Rufato, A.R.; Rufato, L. Avaliação física, química e fitoquímica de frutos de Physalis, ao longo do período de colheita. Revista Brasileira de Fruticultura, v.34, n.4, p.1004-1012, 2012. https://doi.org/10.1590/S010029452012000400006.
Lima, C.S.M.; Gonçalves, M.A.; Tomaz, Z.F.P.; Rufato, A.R.; Fachinello, J.C. Sistemas de tutoramento e épocas de transplante de physalis. Ciência Rural, v.40, n.12, p.2472-2479, 2010. https:// doi.org/10.1590/S0103-84782010001200006.

Manoli, G.; Huang, C.; Bonetti, S.; Domec, J.; Marani, M.; Katul, G. Competition for light and water in a coupled soil-plant system. Advances in Water Resources, v.108, p.216-230, 2017. https:// doi.org/10.1016/j.advwatres.2017.08.004.

Mezzalira, É.J.; Villa, F.; Piva, A.L.; Santin, A.; Melgarejo, M.A.A. Initial development of physalis species under growing environments. Revista de Ciências Agroveterinárias, v.16, n.3, p.293-301, 2017. https://www.periodicos.udesc.br/index.php/agroveterinaria/ article/view/223811711632017293/pdf. 01 Oct. 2020.

Moura, P.H.A.; Coutinho, G.; Pio, R.; Bianchini, F.G.; Curi, P.N. Plastic covering, planting density, and prunning in the production of cape gooseberry (Physalis peruviana L.) in subtropical region. Revista Caatinga, v.29, n.2, p.367-374, 2016. https://doi. org/10.1590/1983-21252016v29n213rc.

Mourão, I.; Brito, L.M.; Moura, L.; Ferreira, M.E.; Costa, S.R. The effect of pruning systems on yield and fruit quality of grafted tomato. Horticultura Brasileira, v.35, n.2, p.247-251, 2017. https://doi.org/10.1590/s0102-053620170215.

Muniz, J.; Kretzschmar, A.A.; Rufato, L.; Pelizza, T.R.; Rufato, A.R.; Macedo, T.A. General aspects of physalis cultivation. Ciência Rural, v.44, n.6, p.964-970, 2014. https://doi.org/10.1590/ S0103-84782014005000006.

Muniz, J.; Marchi, T.; Coldebella, M.C.; Rufato, L.; Kretzschmar, A.A. Crescimento vegetativo e potencial produtivo de fisális. Revista de Ciências Agroveterinárias, v.14, n. 1, p.15-23, 2015. https://revistas.udesc.br/index.php/agroveterinaria/article/ view/5764/4230. 01 Oct. 2020.

Olivares-Tenorio, M.; Dekker, M.; Van Boekel, M.A.J.S.; Verkerk, R. Evaluating the effect of storage conditions on the shelf life of cape gooseberry (Physalis peruviana L.). LWT, v.80, p.523-530, 2017. https://doi.org/10.1016/j.Iwt.2017.03.027.

Pereda, M.S.B; Nazareno, M.A.; Viturro, C. Nutritional and antioxidant properties of Physalis peruviana L. fruits from the Argentinean Northern Andean region. Plant Foods for Human Nutrition, v.74, p.68-75, 2019. https://doi.org/10.1007/s11130018-0702-1.

Rodrigues, F.A.; Penoni, E.S.; Soares, J.D.R.; Silva, R.A.L.; Pasqual, M. Caracterização fenológica e produtividade de Physalis peruviana cultivada em casa de vegetação. Bioscience Journal, v.29, n.6, p.1771-1777, 2013. http://www.seer.ufu.br/index. php/biosciencejournal/article/view/21859/13414. 01 Oct. 2020.

Rodrigues, M.H.B.S.; Lopes, K.P.; Silva, J.G.; Pereira, N.A.E.; Paiva, F.J.; Sá, J.M.; Costa, C.C. Phenological characterization and productivity of the Physalis peruviana L., cultivated in greenhouse. Journal of Agricultural Science, v.10, n.9, p.234243, 2018. https://doi.org/10.5539/jas.v10n9p234.

Silva, D.F.; Pio, R.; Soares, J.D.R.; Nogueira, P.V.; Peche, P.M.; Villa, F. The production of Physalis spp. seedlings grown under different-colored shade nets. Acta Scientiarum. Agronomy, v.38, n.2, p.257-263, 2016. https://doi.org/10.4025/actasciagron. v38i2.27893. 
Silva, D.F.; Villa, F.; Barp, F.K.; Rotili, M.C.C.; Stumm, D.R. Conservação pós-colheita de fisális e desempenho produtivo em condições edafoclimáticas de Minas Gerais. Revista Ceres, v.60, n.6, p.826832, 2013. https://doi.org/10.1590/S0034-737X2013000600011.
Streck, N.A.; Pinheiro, D.G.; Zanon, A.J.; Gabriel, L.F.; Rocha, T.S.M.; Silva, M.R. Effect of plant spacing on growth, development and yield of cassava in a subtropical environment. Bragantia, v.73, n.4, p.407-415, 2014. https://doi.org/10.1590/1678-4499.0159. 